WIDER Working Paper 2015/037

\title{
'Embedded' assistance: Finn Church Aid's secondment in Somalia
}

Rauli S. Lepistö, ${ }^{1}$ Rachel M. Gisselquist, ${ }^{2}$ and Jussi Ojala ${ }^{3}$

March 2015 
Abstract: Donors face distinct challenges in operating in fragile states and supporting the building of state capacity. This paper explores one type of assistance - the 'embedding' of highly-skilled staff members within local government agencies - through a unique case study of Finn Church Aid's experience with secondment in Somalia. Building upon FCA's previous work in Somalia, its staff member worked as part of the Transitional Federal Government's Ministry of Constitutional Affairs and Reconciliation to assist in the implementation of the roadmap designed to end transitional governance in the country. Although a number of such initiatives exist, few studies have explored how, why, and whether they work. Drawing on unique access to FCA staff and documents, as well as interviews with Somali stakeholders, donor representatives, and others, the paper explores FCA's experience and impact through this initiative, one way in which a non-state actor has provided tangible, relatively low cost support to a fragile state.

Keywords: Fragile states, foreign aid, peace-building, human rights-based approach, local ownership, Somalia

JEL classification: F35, F51, H11, O22

${ }^{1}$ Independent researcher; 2UNU-WIDER; 3Finn Church Aid; corresponding author: raulilepisto@gmail.com

This study has been prepared within the UNU-WIDER project 'Foreign Aid: Research and Communication' directed by Tony Addison and Finn Tarp.

Copyright (C) UNU-WIDER 2015

ISSN 1798-7237 ISBN 978-92-9230-922-0

Typescript prepared by the Lisa Winkler at UNU-WIDER.

UNU-WIDER gratefully acknowledges specific programme contributions from the governments of Denmark (Ministry of Foreign Affairs, Danida) and Sweden (Swedish International Development Cooperation Agency-Sida) for ReCom. UNU-WIDER also gratefully acknowledges core financial support to its work programme from the governments of Denmark, Finland, Sweden and the United Kingdom.

The World Institute for Development Economics Research (WIDER) was established by the United Nations University (UNU) as its first research and training centre and started work in Helsinki, Finland in 1985. The Institute undertakes applied research and policy analysis on structural changes affecting the developing and transitional economies, provides a forum for the advocacy of policies leading to robust, equitable and environmentally sustainable growth, and promotes capacity strengthening and training in the field of economic and social policy-making. Work is carried out by staff researchers and visiting scholars in Helsinki and through networks of collaborating scholars and institutions around the world.

UNU-WIDER, Katajanokanlaituri 6 B, 00160 Helsinki, Finland, wider.unu.edu

The views expressed in this publication are those of the author(s). Publication does not imply endorsement by the Institute or the United Nations University, nor by the programme/project sponsors, of any of the views expressed. 


\section{Introduction}

On 2 April 2012, three Finn Church Aid (FCA) specialists met with the Transitional Federal Government of Somalia's (TFG) Minister of Constitutional Affairs and Reconciliation, Abdi Hosh. They asked Hosh how FCA could support his Ministry, which had just been entrusted with the responsibility of overseeing significant parts of the implementation of a roadmap to guide the ending of political transition in Somalia by 20 August 2012. ${ }^{1}$ It was a crucial state-building process in which TFG was set to be replaced by elected representatives of the Somali people serving under a new constitution. Minister Hosh replied that he wanted FCA's peace-building specialist Mahdi Abdile seconded to work with him at the Ministry of Constitutional Affairs and Reconciliation (henceforth the Ministry). Abdile assumed his post on 23 April 2012, charged with the task of supporting the Ministry in its assigned duties.

Operating in fragile states represents a distinct challenge for donors and NGOs. Indeed, in the worst case, their interventions are criticized for serving to erode state capabilities. ${ }^{2}$ This paper presents an example of how a non-state actor has provided tangible support to a fragile state government, assisting in the process of building capacity to guide the country towards resilience. Development agencies provide a variety of types of assistance toward such ends. Within the broader framework of state-building and peace-building development assistance, FCA's secondment may be grouped together with other aid-funded programmes to support external advisors within government ministries - a form of technical assistance, in this case 'embedded' within local institutions. While a number of such initiatives exist, very little publicly available documentation is available on how, why, and whether they work - on the process, challenges, tensions, and lessons learned from such embedded assistance. Benefiting from unique entrée into FCA's experience in Somalia, this case study speaks directly to this lacuna in the literature. At the same time, it also highlights several aspects to FCA's initiative that make it unique, and may be worth consideration by other organizations operating in fragile state environments. Given Abdile's position within the Ministry, the case speaks in particular to issues of 'local ownership' in aid, illustrating some of the tensions faced by external actors in supporting truly locally owned initiatives. Thus, through a detailed case study of a relatively small-scale project, we hope to speak to several broader issues in the literature.

Overall, the paper argues that Abdile contributed in significant ways to the Ministry's capacity to implement the transition roadmap, despite his overall limited ability to influence changes in policy. The embedded assistance provided by Abdile's secondment gave the Ministry additional means to achieve its main goal of overseeing the successful political transition in Somalia. Although FCA was not willing to set specific objectives for the secondment as Abdile reported directly to Minister Hosh, the initiative nonetheless gave FCA indirect, albeit limited, presence at the core of the Somali state-building process. Thus, even while Abdile worked within an environment that did not always carry out activities as FCA might have preferred, his presence within the Ministry also allowed for the promotion of some of FCA's guiding principles. From FCA's perspective, as well

\footnotetext{
${ }^{1}$ Somalia has been a subject of interim governance since 2000 when the Transitional National Government (TNG) was established. The Transitional Federal Government replaced TNG in 2004. It should be noted that throughout the existence of these governance structures, their ability to actually govern has been very limited.

2 L. Zanotti, 'Cacophonies of aid, failed state building and NGOs in Haiti: setting the stage for disaster, envisioning the future', Third World Quarterly, 31(5), 2010, pp. 755-71; Rosan Smits and Deborah Wright, 'Engagement with NonState Actors in Fragile States: Narrowing Definitions, Broadening Scope', CRU Report, Clingendael Netherlands Institute of International Relations, 2012, p. 8.
} 
as that of the Minister, the secondment was an overall success, offering a model that both would hope to build upon in future.

The paper draws on interviews with Somali stakeholders, selected FCA staff, and donor representatives. It also builds on FCA's organizational memory and relevant written documents as well as on secondary sources. Further support is sought from Email correspondence that the lead author was given access to during the research phase of the paper. This study is intended as an objective study of the secondment arrangement. It should, however, be noted that one of the authors is a senior adviser on the right to peace at FCA and has worked with FCA since 2008, allowing the paper to benefit from FCA's institutional memory.

The first part of this paper situates this study within the broader policy and research literature, highlighting FCA's secondment as a form of 'embedded' assistance for state-building with strong potential for helping to address challenges of local ownership. The second situates the case study within the context of FCA's mandate, history, and current projects in Somalia. It explores how the organization's understanding of its mandate and role in supporting fragile states evolved to the degree where providing capacity support to a fragile government became possible, and reviews the secondment from a programmatic point of view. The third section explores the impact of the secondment, in particular highlighting the assessments of both participants and observers. It explores some of the extenuating factors in assessing impact, in particular the capacity limitations faced by Abdile during the secondment. The paper concludes by considering the secondment initiative within the broader context of political transition and establishing new state institutions in Somalia.

\section{Supporting state-building and local ownership through 'embedded' assistance}

Fragile states and conflict situations have some of the most pressing development and humanitarian needs and addressing these needs will remain central to development assistance post2015. ${ }^{3}$ Operating in fragile environments thus remains core to the mandates of many development and humanitarian NGOs, including FCA. Somalia, the quintessential 'failed' state, has long occupied one extreme of the fragility spectrum, with humanitarian and development needs well documented. ${ }^{4}$

Operating in fragile environments poses distinct challenges in comparison to development assistance in more stable environments - even ones in which economic indicators and levels of poverty may be similar. For instance, addressing issues of security for operations and personnel clearly imposes additional costs, risks, and complexity. At a more abstract level, one of the most fundamental tensions relates to issues of local ownership. Donors have committed to local ownership in aid operations, one of the core principles of the Paris Declaration on Aid Effectiveness (2005), reaffirmed in the Accra Agenda for Action (2008) and the New Deal for Engagement in Fragile States (2011). At the same time, fragile states are particularly ill-equipped to fully 'own' their development processes; notwithstanding the strong will and capacity of many individuals and some organizations within them, a fragile state - by definition - has extremely weak state capacity,

\footnotetext{
3 OECD, Fragile States 2014: Domestic Revenue Mobilisation in Fragile States, Paris: OECD, 2014; World Bank, World Development Report. Conflict, Security, and Development, Washington, DC: World Bank, 2011.

${ }^{4}$ See, e.g., Ken Menkhaus, 'State Failure, State-Building, and Prospects for a "Functional Failed State" in Somalia', The ANNALS of the American Academy of Political and Social Science, 656(1), pp. 154-172.
} 
legitimacy, and authority. ${ }^{5}$ How to support fragile states to build the capacity, legitimacy, and authority required to effectively and fully lead and manage their own development processes, in a manner at the same time consistent with local ownership, is thus a major tension for donors operating in these environments. ${ }^{6}$

Likewise, supporting local ownership while also facilitating improvements in state capacity and better governance remains a major tension for donors in developing countries more generally. ${ }^{7}$ Indeed, critics argue that development assistance can both contribute to the weakening of state capacity and legitimacy, as well as effectively hinder the ability of states to raise their own revenues. ${ }^{8}$ In addition, in terms of 'how to' support more capable and legitimate states, there remains considerable debate among researchers and practitioners over best practices in core thematic areas, such as reform of the civil service, public financial management, tax systems, and policing. ${ }^{9}$

Efforts by development actors to support the emergence of more capable and legitimate states can be grouped into four broad categories. The first consists of support or incentives for institutional reforms of existing state organizations and practices, such as major restructuring of the civil service, public financial management system, judiciary, legislature, or electoral system. A second broad category consists of capacity-building efforts, such as job training or 'train the trainers' initiatives, geared to developing the skills and experience of individuals working within such institutions. A third broad category, technical and capacity assistance, provides additional external support when domestic capacity is insufficient. Finally, a fourth category includes efforts to act in place of the state to fulfill functions normally undertaken by more capable states, such as the provision of public services - labeled 'parallel institutions' for short. Humanitarian assistance might loosely be classified here. In terms of development, efforts tend to involve support for more durable 'independent' institutions operating in parallel to government agencies. Given the difficulties in reforming existing institutions, such institutions are seen to benefit for instance from their autonomy from existing (dysfunctional) organizations and their ability to work outside the traditional civil service, which may facilitate payment of higher salaries and attracting of more skilled employees. While development assistance has generally focused more on interventions of

\footnotetext{
${ }^{5}$ Rachel M. Gisselquist, 'Aid and Institution-Building in Fragile States: What Do We Know? What Can Comparative Analysis Add?', The ANNALS of the American Academy of Political and Social Science, 656(1), pp. 6-21; OECD, The Missing Piece: Improving International Support to the Peace Process, Paris: OECD, 2012; OECD/DAC, Principles for Good International Engagement in Fragile States and Situations, Paris: OECD, 2007.

${ }^{6}$ Derrick W. Brinkerhoff, 'Developing capacity in fragile states', Public Administration and Development, 30(1), pp. 66-78; UNU-WIDER, Position Paper: Aid, Governance, and Fragility, Helsinki, Finland: UNU-WIDER, 2014.

${ }^{7}$ David D. Booth, 'Aid effectiveness: bringing country ownership (and politics) back in', Conflict, Security \& Development, 12(5), 2012, pp. 537-58; Rachel M. Gisselquist and Danielle Resnick, 'Aiding Government Effectiveness in Developing Countries', Public Administration and Development, 34(3), 2014, pp. 141-48; Martin Sjöstedt, 'Aid Effectiveness and the Paris Declaration: A Mismatch between Ownership and Results-Based Management?', Public Administration and Development, 33(2), 2013, pp. 143-155.

${ }^{8}$ See, e.g., Deborah Bräutigam and Stephen Knack, 'Foreign Aid, Institutions and Governance in Sub-Saharan Africa', Economic Development and Cultural Change, 52(2), 2004, pp. 255-85; Lant Pritchett, Michael Woolcock, and Matt Andrews, 'Looking like a state: Techniques of persistent failure in state capability for implementation', The Journal of Development Studies, 49(1), 2013, pp. 1-18.

9 See, e.g., Matt Andrews, The Limits of Institutional Reform in Development: Changing Rules for Realistic Solutions, Cambridge: Cambridge University Press, 2013; Odd-Helge Fjeldstad, 'Tax and Development: Donor Support to Strengthen Tax Systems in Developing Countries', Public Administration and Development, 34(3), 2014, pp. 182-193; Otwin Marenin, 'Styles of Policing and Economic Development in African States', Public Administration and Development, 34(3), 2014, pp. 149-161; Sarah Repucci, 'Designing Effective Civil Service Reform: Lessons from Past Experience', Public Administration and Development, 34(3), 2014, pp. 207-218.
} 
the other three types, Collier for one advocates more development attention to such parallel institutions for service provision. ${ }^{10}$

Within this framework, FCA's secondment may be grouped broadly with other aid-funded programmes to support external advisors within government ministries - a form of technical and capacity assistance. While more standard technical assistance often involves considerable coordination and work with government agencies, this approach takes a step further in the degree to which external advisors are 'embedded' within local institutions and accountable directly to supervisors within these institutions. Some such initiatives also involve elements of capacitybuilding as the embedding of external advisors may be seen as playing a role in building domestic capacity through example and interaction, 'knowledge transfer', and (sometimes) direct training of local colleagues. Depending on the size of such programmes, an element of 'parallel institutions' may also be at work.

Among such programmes, the Overseas Development Institute (ODI)'s Fellowship Scheme is perhaps the best known. Since it began in 1963, it has placed over a thousand post-graduate economists and statisticians in the public sectors of developing countries to work as local civil servants. ${ }^{11}$

The Scott Family Liberia Fellows is another such programme, although smaller than ODI's with roughly six fellows per year since it began operations in mid-2007. Initiated with a grant from Ed Scott, the programme was originally managed by the Center for Global Development (CGD) and subsequently by John Snow, Inc. (JSI). Liberia Fellows "typically work as "special assistants" to Ministers or other officials, taking on a wide variety of tasks, ranging from economic affairs, public policy, agriculture, health, legal, speechwriting, ministerial co-ordination and administration'. They aim to 'support the Ministers in their full range of activities and to make them more effective and efficient in all that they do.' ${ }^{12}$

Also in Liberia is the more recently initiated Carter Center and Transnational Law Institute of Washington and Lee University School of Law (W\&L) Liberia Law Fellows Program, which expects to place law school graduates in government offices at the Ministry of Justice, Ministry of Commerce, Ministry of Internal Affairs, Ministry of Agriculture, Ministry of Public Works, Ministry of Health, Judicial Institute, and Land Commission. Both the Carter Center and W\&L have been engaged in other projects on access to justice in Liberia, since 2006 and 2008, respectively, and the programme builds upon these activities. ${ }^{13}$

An earlier example is the Africa Fellows programme led by Professor Carroll Wilson of the Massachusetts Institute of Technology (MIT). It operated from 1959 to the mid-1960s, sending primarily MIT business and law school graduates to work in ministries in various African countries - most either newly independent or on the verge of independence. A report on the programme's

${ }^{10}$ Paul Collier, 'How to Spend it: The organization of public spending and aid effectiveness', WIDER Working Paper WP2012/005, Helsinki: UNU-WIDER.

11 See www.odi.org/fellowship-scheme.

12 JSI, 'Liberia Fellows Program', n.d. (at: www.jsi.com/JSIInternet/IntlHealth/project/display.cfm?ctid=na\&cid=na\&tid=40\&id=5028, last accessed 11 December 2014).

13 The Carter Center and W\&L, 'Liberia Law Fellows Program', n.d. (at: law.wlu.edu/deptimages/carter\%20fellows/Law\%20Fellows\%20report-April\%2024.pdf, last accessed 11 December 2014). 
founder notes that 'Wilson is said to have considered it the highest compliment to the program when the U.S. ambassador to Uganda complained that the African Fellow in Kampala was acting as if he were working for the Ugandans. "He is", Wilson agreed". ${ }^{14}$

While at least the first two of these initiatives are quite well-known within development policy circles, to the best of our knowledge no major comprehensive study has been done to enumerate all such efforts, much less to systematically analyse them within the context of one of their key aims - to support governance and state capacity in weak and fragile states. Nor is there much publicly available documentation on the process, challenges, tensions, and lessons learned from such efforts at embedding employees within local government institutions - in particular from the perspective of the external agencies supporting them. As Wilson's comment above underscores, clear tensions are apparent in terms of local versus external accountability and, by extension, ownership. How do the external agencies supporting such initiatives view and address such tensions? The unique entree we had into FCA's experience in Somalia allows us to speak directly to this lacuna in the literature through this case study. Thus, while FCA's secondment in Somalia was a relatively small-scale project - even in comparison to other such initiatives of this broad type - this case can contribute to the discussion of broader issues in the literature on state-building and local ownership.

Finally, it is also worth noting that while FCA's secondment in Somalia is like these other initiatives in many ways, it is also unique in some key ways, which might be built upon in other initiatives in future. First, as noted, it operated on a smaller-scale (one seconded employee only) and over a limited time period, without an expectation of continuation. Second, it functioned during a period of more extreme political instability than any of the other programmes noted above. While Liberia for instance is also a fragile state, the Scott Fellows programmes there began only in the postconflict period.

Third, in terms of the core purposes of the initiative, FCA's sole purpose in the secondment was to support state-building in Somalia by lending capacity during a crucial phase of the peace process. By contrast, while support for state capacity is also a goal of the other initiatives, all also equally highlight benefits for 'fellows' in addition to those for the host country. Fellows in turn generally apply through competitive recruitment processes and many, if not most, have few prior ties to their host countries. Abdile, on the other hand, is of Somali-decent, with strong personal ties and commitment to the development of the country. Perhaps only some of the Scott Fellows are somewhat similar in this latter sense - as a handful of Liberian fellows have participated, some of whom have stayed on in Liberian government. ${ }^{15}$

Fourth, in contrast to the other initiatives, FCA's secondment provided more 'capacity' assistance than 'technical' assistance. Indeed, while clearly capable and highly skilled in peace-building work, Abdile did not possess the sort of technical skills in economics, statistics, or law emphasized by the other programmes. Thus, the sharing or transfer of this sort of 'technical' knowledge was not

\footnotetext{
14 'Activist on the World Stage: Carroll Wilson Remembered', The MIT Tech Review, February/March 1984 (made available by Carroll L. Wilson Award Committee at: web.mit.edu/idi/carroll_wilson_award/CLW-Activist.pdf, last accessed 11 December 2014).

15 Todd Moss and Stephanie Majerowicz, 'Beam Me Back, Scotty: How Young Liberians are Coming Home', Center for Global Development, 17 April 2012 (at: http:/ /www.cgdev.org/blog/beam-me-back-scotty-how-young-liberiansare-coming-home-0, last accessed 15 December 2014).
} 
core to the effort. Rather, Abdile brought a less clearly defined set of management and analytical skills and peace-building experience.

Fifth, the secondment is unique in the degree to which it supported local ownership of assistance. While local ownership plays a role in all of the initiatives noted above in the sense that fellows work directly for local government agencies and report to local supervisors, even if paid by external agencies, the Somalia secondment was unique in that it was also locally initiated: the Minister specifically requested the secondment.

\section{$3 \quad$ FCA and its work in Somalia}

FCA is the largest development co-operation NGO in Finland, with an annual turnover of 35 million Euros. It works extensively in situations of fragility with a twin focus on advocacy and development support. FCA's work began in Somalia in 2007. Its programmatic entry in Somalia was focused, concentrating on supporting religious leaders in local level conflict resolution in northern Somalia and Somaliland (Peace Initiative Project, PiP). Given the intertwined nature of religious and traditional (clan) leaders in Somalia, FCA and its partners, the Danish Refugee Council and International Horn University, broadened the scope of the conflict resolution project to encompass both social groups. The project successfully facilitated the resolution of more than a dozen clan-based conflicts in Somalia between 2008 and 2012. ${ }^{16}$

FCA discussed and decided upon key advocacy targets in 2009 and selected 'Peace in Somalia' as one of the main focuses. Within Somalia, FCA sought to support the advocacy of religious leaders for peace and reconciliation in mosques, communities, and conflict hotspots (as part of PiP). Internationally, FCA's plan stressed influencing UN decision-making on Somalia especially with the goal of supporting open and participatory peace processes. In Finland, FCA pursued closer co-ordination and collaboration with the Somali diaspora. ${ }^{17}$

FCA's engagement with the UN Political Office for Somalia (UNPOS) was initiated in earnest during the latter half of $2010 .{ }^{18}$ FCA and UNPOS formed a joint project in November 2010, Somalia Outreach and Reconciliation (SOR) Initiative, which sought to include the Somali religious and clan elders to the federal level peace- and state-building work from which they had been sidelined for decades. ${ }^{19}$ This project was a groundbreaking step for FCA, as it provided a concrete case where FCA facilitated dialogue and co-operation between grassroots actors (with whom FCA had co-operated for years and gained their trust) and the Security Council-mandated UN agency.

\footnotetext{
16 The PiP project is credited for having provided successful dispute resolution to 11 conflicts in Somaliland and Puntland between 2008-10 and to three conflicts in Central Somalia regions of Mudug and Galguduud.

${ }^{17}$ FCA, "Peace in Somalia 2009-2012', unpublished document on the advocacy plan.

${ }^{18}$ See Rauli Lepistö, 'Building a Piece of Peace: Finn Church Aid's Outreach and Reconciliation Project in Somalia', CMC Finland Studies in Peacebuilding and Civilian Crisis Management, 4(1), 2013, Helsinki: Crisis Management Centre Finland (CMC Finland), pp. 12-14.
}

${ }^{19}$ Lepistö, p. 5. 


\subsection{FCA's mandate: a rights-based approach to development assistance in fragile situations}

Underlying FCA's work is its commitment to a rights-based approach (RBA). It describes the core RBA principles for its programmatic work as follows:

Contrary to needs, rights always trigger obligations. They exist in a relationship between rights-holders and duty-bearers, which highlights the importance of accountability and dialogue between them. Change requires working in a strategic way towards the duty-bearers that hold decisive positions of power and control. The recognition of this dual relationship is key to the practical implementation of RBA. ${ }^{20}$

Central to the approach is to identify the root causes of poverty and lack of realization of rights. As poverty is not considered merely as a lack of material goods but as injustice, denial of human rights, and equal participation, the tools to promote positive development, derive from creating possibilities to access power and resources, e.g. through advocacy and capacity-building.

RBA as a way of work stresses the imperative of local ownership. In FCA's work, this is highlighted in the stated focus on strengthening the accountability between (local) 'rights-holders' and 'dutybearers' as well as in the emphasis that process is as important as the outcome. ${ }^{21}$ In Somalia, this approach was adopted from the outset. FCA's role in PiP was deliberately in the background, concentrating on facilitating mediation processes and capacity-building, rather than driving them. On the other hand, focus on process and participation imply that change is gradual and patience is required by all stakeholders. As will be discussed later in the article, the belief in local ownership as well as the importance of the gradual process has inbuilt tension that matter when evaluating the success of the secondment.

In 2009, FCA assumed the lead in an advocacy working group that chose fragility as its main theme. ${ }^{22}$ Although fragility had been touched upon in FCA prior to Abdile's secondment, FCA had not gone deep on discussing its own actions in support of a duty-bearers' capacity. Rather, the focus was on analysis of the implications of fragility to rights-holders and suggestions of action by the EU and the international community as moral duty-bearers. ${ }^{23}$ After 2010, FCA's engagement with UNPOS as part of the SOR Initiative was a groundbreaking step for FCA in this sense, in providing the organization an opportunity to move from theory to practice on RBA and its stated focus on 'the interrelationship between the individual at the micro level and the state and the international community at the macro level'. ${ }^{24}$

\footnotetext{
${ }^{20}$ FCA, 'Rights Based Approach - Principles for FCA Programme Work', unpublished FCA document, 2012.

${ }^{21}$ FCA, 2012, p. 1: 'We should always prioritize local ownership and the agency of the rights-holders'

22 APRODEV (the Association of World Council of Churches related Development Organizations in Europe), 'Background paper on fragile states and situations', unpublished paper, March 2009. The document emphasized the role of NGOs, coherence, and local ownership in fragile settings. It also stressed the 'importance of supporting ... state-building focus to inclusive society building'.

${ }^{23}$ Boesen J. Kirkemann and T. Martin, Applying a rights-based approach - an inspirational guide for civil society, Copenhagen: Danish Institute of Human Rights, 2007 (at: http://www.humanrights.dk/files/pdf/Publikationer/applying a rights based approach.pdf), p. 12.
}

${ }^{24}$ Kirkemanm and Martin, p. 12. 


\subsection{FCA's capacity support to Somalia's TFG}

FCA's secondment of Abdile emerged through the SOR Initiative. In terms of addressing explicitly state fragility in Somalia, and the responsible duty-bearer, the TFG, the SOR initiative started slowly. While dialogue between representatives of local communities and UNPOS was seen as successful ${ }^{25}$, the TFG became part of the activities only towards its end. ${ }^{26}$ FCA representatives met Minister Hosh for the first time in November 2011 upon the recommendation of UNPOS' Deputy Special Representative of the Secretary General, Christian Manahl. Subsequently, FCA staff met TFG's Ministers several times, especially Hosh and the Minister of Interior and National Security, but also the Prime Minister, in the margins of the London Somalia Conference in 2012. ${ }^{27}$ Similarly FCA saw increasingly the significance of co-operation with TFG as there was now a great convergence between the objectives of SOR and the roadmap. ${ }^{28}$

FCA did not expect a request to second an FCA staff member to TFG. While the proposed secondment was well-aligned with the RBA and could be seen as logical continuation of the SOR Initiative, it still posed several challenges for FCA starting from the fact that Abdile's calendar was already full. Financial issues were even more concerning. Even though the estimated cost of the secondment was quite small, FCA lacked the internal resources to fully support Abdile's secondment on its own and looked for other sources of funding. ${ }^{29}$ UNPOS endorsement was considered at first, but it soon became clear that obtaining any funds or clearance from UNPOS, in a manner that Abdile could speak on behalf of UNPOS, was out of the question. The Ministry for Foreign Affairs of Finland (MFA) was the next turning point for financial support. MFA staff at the mediation unit immediately understood the value of the proposed secondment, yet it took until the end of May 2012 for FCA to receive the formal approval, during which time FCA continued working with TFG through its own funding. ${ }^{30}$ Upon request, Minister Hosh submitted Abdile's Terms of Reference (ToR) to FCA. It was framed as follows:

Mahdi Abdile would be a consultant on the implementation of Road map as it relates to end of transition processes, including the convening of the Constituent Assembly on May 15, 2012 and the traditional elders on April 25, 2012. ${ }^{31}$

Minister Hosh asked FCA not to second Abdile as FCA staff as this could provide ammunition for someone who would wish to harm the process of ending the transition by falsely portraying FCA as a missionary organization, and by doing so put not only the Minister himself, but also the whole Government, under unwanted accusations. FCA thus let Abdile take a leave of absence for

\footnotetext{
25 The Security Council on Somalia, 28 April 2011, the Secretary General of the UN offers a paragraph to the activities of the joint project. UNSC, 2011, p. 11.

${ }^{26}$ The funds of the final planned activity of the joint project with UNPOS were transferred to TFG as it was convening the Somali elders in Mogadishu in April 2012. See Lepistö, 2013, p. 28.

${ }^{27}$ Interview regarding the role of Somali elders and FCA's contribution to ending the transition, with Prime Minister Abdiweli Mohamed Ali and Minister of Interior Abdisamad Moallim Mohamoud, London, 23 February 2012.

${ }^{28}$ The roadmap was further specified through the National Constitutional Conferences in Garowe in December 2011 and February 2012, the Galkayo Communique of the principal political stakeholders from March 2012 and Addis Ababa Communiqué from May 2012. The centrality of the clan elders in the political process was incrementally pronounced in the outcomes of these meetings.

29 The total budget of the capacity support to TFG was 60,400 Euros.

30 The MFA subsequently allowed FCA to count the start of the project from 22 April 2012.

31 Telephone interview with Hosh, Helsinki, 8 September 2013.
} 
the duration of the secondment and hired him as consultant without formal bond to FCA, yet with the opportunity to take advantage of FCA's service functions such as contractual help, travels, financial arrangements, and support on security arrangements. The secondment was extended twice, from the initial end date of 31 July 2012 to 20 August 2012 (end of transition) and, after a request by then caretaker Minister Hosh, to 15 September 2012. Already during the first term of the secondment, it was clear that MFA's original funding would not be sufficient to cover all expenses. Security-related costs in particular burdened the budget more than anticipated. ${ }^{32}$ In the end, the secondment program was 65 per cent covered through MFA funds and 35 per cent through FCA's funds. ${ }^{33}$

\section{Assessing the impact of FCA's secondment}

Overall, we find that Abdile contributed to the Ministry's capacity to implement the transition roadmap, despite his overall limited ability to influence changes in policy. The embedded assistance provided by the secondment gave the Ministry additional means to achieve its main goal, but the initiative was not without tensions and challenges. Broadly, we find clear tradeoffs between FCA's commitment to the local ownership of the secondment and some of FCA's core rights-based principles and objectives. In other words, in being directly accountable to the Minister, not FCA, Abdile did not always pursue activities as he would have had his work been directed by FCA. At the same time, his direct accountability to the Minister was a condition of his presence within the Ministry and his presence within the Ministry also allowed for the promotion of some of FCA's guiding principles and core commitment to supporting the state-building process in Somalia.

This section draws heavily on the perspectives of those involved in the secondment - particularly Abdile - to consider how the impact of such an initiative might be evaluated. While we thus cannot draw conclusive arguments, the findings do suggest that although Abdile was very centrally positioned regarding the transition process, his ability to have an effect on the quality of the process of ending the transition was limited. This limitation originates from his position within the Ministry, working directly under the supervision of Minister Hosh. Therefore his position was different than if he had worked for FCA. The Ministry's role was to oversee the implementation of the roadmap as agreed in connection constitutional conferences commonly referred to as Garowe 1 and 2. Additional amendments were agreed in the Galkayo meeting where the Somali 'elders' were given the authority to select the parliament and an Elders Council would be created for this purpose. The Galkayo amendment also outlined the basis of selection by which the elders would be included to the Elders Council.

Essentially the work was to oversee the implementation of a political process where significant decisions had already been made. Any perceived impact of the secondment further has to be considered as originating from the Ministry's work. Minister Hosh reports that Abdile's contribution was very valuable, but the process would also have been completed without him. ${ }^{34}$ Abdile's own account suggests the same. He describes how he had to remain constantly (in his words) 'neutral', including when he felt that some issues were not followed through in an ideal or sustainable matter. ${ }^{35}$ The Somali interlocutors were nonetheless content about the arrangement

\footnotetext{
32 Abdile had personal security costs of roughly US $\$ 400$ per day.

33 Private donations and other un-earmarked funding.

34 Interview with Hosh, 2013.

35 Interview with Abdile, Helsinki, 2 August 2013.
} 
highlighting the benefits from the direct relationship between themselves and Abdile. ${ }^{36}$ Abdile's colleague from the Ministry stresses the fact that Abdile was able to physically come to Somalia and work with them on daily basis, which was a most definite asset for them. ${ }^{37}$ For Hosh, it also seemed to increase the level of local ownership as Abdile worked directly under the Ministry, without outside entanglements. Indeed the direct relationship seemed to have extra meaning in this particular case, due to the politically charged nature of the secondment. Abdile also introduced ideas of his own during the process. He could not claim ownership of these ideas, however, and had to circulate the ideas through the Ministry's bureaucracy. This was another element that Hosh appreciated as it made him feel that Abdile was truly a part of his team and not a solo player with his own agenda. ${ }^{38}$

\subsection{Limited capacity}

Among the key factors highlighted by those involved in the secondment in influencing Abdile's ability to perform within the Ministry was the existing capacity of the Ministry itself -which in turn was part and parcel of the fragile nature of the Somali state. Prior to Abdile's secondment, the Ministry was only two persons strong, consisting of Minister Hosh and his cabinet secretary. ${ }^{39}$ Limited resources prevented Hosh from hiring more staff and in this regard it was essential that Abdile's secondment was financed externally. ${ }^{40}$ In addition, Abdile notes the lack of expertise within the Ministry, particularly on the constitutional matters core to its work. While Minister Hosh had a legal education, he did not have experience on constitutional matters. The lack of institutional memory and basic recordkeeping within the institution further meant that basic and key documents such as concept notes and other memos had to be drafted from scratch, rather than based on existing models. ${ }^{41}$ Hosh narrates how during the long war several ministers had been killed and virtually everything had collapsed. Offices, ministries, and libraries were destroyed which led to a 'loss of memory'. Hosh says that among other things, Abdile's assistance was much appreciated as there were no potential employees available with the required experience. ${ }^{42}$

During the SOR Initiative in 2010, UNPOS saw that there was a need to give political support to the elders in order to prevent them from being ridiculed or exposed to corruption. UNPOS worked together with FCA to inform the elders about the process of ending the transition. Due to this history, it did not come as a surprise to Abdile that the elders' limited experience with politics prior to the constitutional process formed a challenge for the overall process. Thus, it was natural that Abdile's ToR included a duty to provide for civic education, which essentially meant informing the elders about their role in the process via seminars and workshops which Abdile designed and facilitated. ${ }^{43}$ Regardless of the past support, there was still a great demand for such education as many of the elders had not yet been fully informed about their exact role and

\footnotetext{
36 Telephone interview with Hosh and K. Hassan, Helsinki, 2 July 2013

${ }^{37}$ Interview, Hassan.

${ }^{38}$ Interview, Hosh.

${ }^{39}$ Interview with Abdile, Helsinki, 2 July 2013.

${ }^{40}$ Interview with Hosh.

${ }^{41}$ Interview, Abdile, 2 August 2013.

42 Interview, Hosh.

43 The topics also included reconciliation and mediation.
} 
responsibility in the process. Sometimes this need to provide education for the elders meant that activities which would have required a day under more organized conditions, took a week. ${ }^{44}$

To summarize, Abdile's work was made more challenging because of lack of human resources, lack of technical expertise within the government, and limited understanding of the elders regarding their exact role in the process of ending the transition. These obstacles illustrate the nature of some of the challenges that both the host government's officials and external actors come across when working within fragile states to support capacity development. What may follow is that extremely weak institutional capacity hinders the very initiatives designed to address it, even when political will supports capacity development - as in this case. While the definition of fragility does include both a lack of will and a lack of capacity, these two elements are a world apart. The risk of an unwilling state (duty-bearer), however, did not materialize with Abdile's secondment as the TFG explicitly expressed its willingness to receive capacity support to carry out its duties.

\subsection{Working for gender equality}

Another key issue highlighted in Abdile's reflections on his experience concerned issues of gender equality. For Abdile, gender equality was a familiar and natural priority in his work at FCA, where it had been one of FCA's strategic focuses since $2009^{45}$ and FCA had already advocated better inclusion of women into Somali politics. ${ }^{46}$

In his embedded role within the Ministry, one of Abdile's tasks was working with women's rights groups which advocated for gender equality. The key issue in this regard was to see the fulfillment of a 30 per cent quota for female representation in the new Federal Parliament of Somalia, a quota which was introduced during the creation of the roadmap and was one of most noticeable features in the Garowe Principles, a milestone during the formulation of the roadmap. Subsequently, the quota was very much on the Ministry's agenda. ${ }^{47}$ Toward this end, Abdile met regularly with women's groups and worked to find ways to bring them together to jointly discuss how to promote their agenda. He also carried their message forward to TFG and other Somali stakeholders. ${ }^{48}$ The elected parliament, however, did not meet the agreed quota. It included 275 representatives, of whom only 14 per cent were women. ${ }^{49}$ This was only a slight improvement from previous women's representation in the attempt to establish a parliament to Somalia (12 per cent in the Transitional Federal Parliament). In explaining this outcome, Abdile notes that the UN could have promoted the quota more forcefully, but did not wish to risk the implementation of the roadmap which was close to fulfillment. ${ }^{50}$ It was then left to the hands of Somalis and particularly to the elders to make sure that the quota would be met. As the principal guardians of the traditional customs of the Somali people, the elders, however, were not the force that would have driven change in gender equality. As one commentator noted: 'Putting the faith of women in the hands

\footnotetext{
${ }^{44}$ Interview, Abdile, 2 August 2013.

${ }^{45}$ FCA Strategy, 2009, p. 7.

${ }^{46}$ FCA facilitated a workshop during the PiP where the elders had gathered to discuss sharia law. In this meeting, the role of women rose to the agenda resulting to an understanding that there were no theological obstacles to include women into politics.

47 Interview, Hosh, 2013.

48 Telephone interview with H. Ismail, Helsinki, 28 August 2013.

49 A. Cawo, 'Marginalising women in Somali politics', Al Jazeera, 24 August 2013 (at: http://www.aljazeera.com/indepth/opinion/2012/08/201282385318698928.html).

${ }^{50}$ Interview, Abdile 2 July 2013.
} 
of elderly men in a patriarchal society was misguided ideology. ${ }^{51}$ The (female) co-chair of the Technical Selection Committee (of eligible Members of Parliament) also made a similar observation, arguing that the three main factors that kept women's representation lower than agreed were the male- dominant culture, (some) religious interpretations which argued against the inclusion of women into Somali politics, and finally selfish views of too many men who did not want to share the results gained in the political process with women. ${ }^{52}$ While working with women's groups, Abdile also observed that women were divided in their opinion on whether they should focus on achieving the quota or rather should have strong women politicians as leaders who could drive change more forcefully. ${ }^{53}$

The example illustrates the difficulty of effectively implementing gender equality objectives, regardless of whether these objectives on paper enjoy a strong backing of the international community. Abdile draws an interesting comparison to peace-building: 'In peace work the state of affairs is such, that once a deal is done, there must be someone who will oversee its implementation. Otherwise everyone knows already beforehand that it will not hold. With political deals, it is almost the same. ${ }^{, 54}$

\subsection{Deficiencies in representation}

Another key focus of Abdile's work was to co-ordinate the Elders Council. Therefore it was imperative to find and invite the right people to the meeting. Finding the 'real' elders - i.e., the ones who truly represented their communities - was, according to Abdile, the greatest single challenge that the Ministry had during the process. ${ }^{55}$ Abdile had struggled with the same problem already during the SOR Initiative. The questions that had to be constantly reassessed then were: who were the real elders who could truly represent the various Somali clans, and how to keep the delicate clan balance in order? It was initially thought that every Somali can tell the name of his or her clan elder, so consequently one should only ask and the list of elders would write itself. ${ }^{56}$ However, this was not the case. ${ }^{57}$ In Abdile's opinion, the identification of the elders posed some fundamental challenges that had the potential to put the whole process at risk. The process of ending the transition had a sense of urgency to meet the agreed deadline (20 August 2012) which accordingly had an impact on the appointment of elders. In Abdile's assessment, the clans did not always have enough time to properly discuss who would represent them. In such cases the resulting decisions suffered from a lack of consultation from the respective communities, paving the way for potentially wrong decisions. The potential for corruption and political manipulation also increased as the respective communities had less time to properly oversee the activities of their leaders. ${ }^{58}$

\footnotetext{
51 A. Farhia, 'Somali women parliamentarians: the predicament of finding a voice', Hiraan online, 15 May 2013 (at: http://www.hiiraan.com/op4/2013/may/29375/somali_women_parliamentarians_the_predicament_of_finding_a_ voice.aspx).

${ }^{52}$ Interview, Ismail.

53 Interview, Abdile, 2 August 2013.

54 Interview, Abdile, 2 August 2013.

${ }^{55}$ Interview, Abdile, 2 August 2013.

${ }^{56}$ Lepistö 2013, p. 26.

${ }^{57}$ Another complicating feature was the existence of many self-appointed elders, who were active in the media aiming to increase their status in the eyes of the public. Often it turned out, that these people were not real elders.

58 Interview, Abdile, 2 August 2013.
} 
Abdile had to proceed in his work regardless of knowing that the Elders Council was formed on the basis of politics, not tradition. The agreed composition of the council was defined on the basis of the ' 4.5 clan' formula, a political power sharing deal between the main clans in Somalia where four main clans represent one unit each and the remaining half a unit represents the smaller clans. Traditional leaders are chosen, however, in way that follows tradition, not politics, which raises a question over whether it is possible to apply the 4.5 formula and still have such representation as originally intended when the elders were authorized to choose the parliament during the Galkayo meeting. Abdile estimates that the true number of 'first tier elders', i.e. Dubaabs, is somewhere between 60 and 70 in the whole of Somalia. ${ }^{59}$ Thus, 135 elders would have been too many. The Ministry estimated that from the 135, between 37 and 40 could be described as 'real' elders. If the estimates are accurate, one can safely assume that politics did play a significant role when the composition of the Elders Council was decided, excluding some of the real elders from the process and adding some extra. In Abdile's view, the consultation process fell short in this regard as the primacy in the process of ending the transition was to take the process from one stage to another. Such prioritization limited the Somalis' chances to thoroughly discuss the quality of the process, potentially planting seeds for future tension. ${ }^{60}$ Some have even argued that the process reminded them more of a project than a genuine process, moving from one stage to another, aiming to meet deadlines rather than to build the necessary consensus amongst Somali actors. ${ }^{61}$

\section{Conclusion}

Although FCA's secondment in Somalia was a relatively small-scale project, analysis of this experience, we argue, can contribute to broader discussions in the literature on state-building and local ownership. In particular, it contributes to discussion on aid-funded programmes to support 'embedded' external advisors within government agencies - a form of technical and capacity assistance. A number of such initiatives exist, but little analysis is available about how, why, and even whether they work. Drawing on unique entrée into FCA's experience in Somalia, this case study speaks directly to this lacuna in the literature. Several unique aspects of FCA's secondment - such as the fact that it was locally-initiated and, in comparison to other 'embedded' assistance efforts, operated in a more unstable political environment - may also be worthy of consideration by other development actors.

The relevance of FCA's experience to peace-building and state-building is underscored by the continuing emphasis on local ownership in development assistance and the New Deals emphasis on 'country-owned and -led pathways out of fragility'. ${ }^{62}$ FCA's experience suggests that addressing fragility through such embedded assistance may well increase in popularity in the future. This would require that such assistance be seen by both fragile states and donors alike as an effective and 'locally-owned' means to support state capacities. Notably, feedback from both Hosh and his cabinet secretary suggests that the FCA secondment was praised especially from the perspective of perceived Somali ownership. Furthermore, it is clear that Abdile's secondment contributed to

\footnotetext{
${ }^{59}$ Interview, Abdile, 2 August 2013.

${ }^{60}$ Interview, Abdile, 2 August 2013.

61 A. Atta-Asamoah, Situation Report. Long Walk to Restauration: Lesson from Somalia's Transition Process, Institute for Security Studies, report, July 2013, pp. 1-10.

${ }^{62}$ See www.newdeal4peace.org/.
} 
the Ministry's basic capacity: at the very least, Abdile's secondment increased the Ministry's staff from two to three individuals.

Although FCA was not willing to set definite objectives for the secondment, Abdile's mission was nonetheless a success for FCA as well. Through Abdile, FCA received an indirect presence at the core of the transition process where it was able to support the TFG's capacity and simultaneously support Somali ownership. The secondment served FCA's commitment to a RBA, providing an opportunity to support an incapacitated duty-bearer. The secondment further took FCA forward in its thinking and action when operating in a fragile context, giving content to its commitment to support duty-bearers under the auspices of a RBA. This experience helped to build FCA's own capacity and served to encourage FCA to expand its work to other fragile states, including through contributions to the International Dialogue on Peacebuilding and Statebuilding.

More broadly, it is still too early to say whether the successful ending of the transition will result in peaceful development in Somalia. At the time of this writing, there is no peace in Somalia. Somalia is still amongst the most fragile states in the world. On 20 August 2012, the Federal Parliament of Somalia took over its responsibilities, testament in part to the Ministry's successful overseeing of the roadmap. Observers have raised several strong critiques about the process. ${ }^{63}$ Indeed, several key critiques are suggested above. For instance, gender quotas were not met in parliament and the composition of the Elders Council was to some degree based on political interests and not genuine clan representation.

However, despite such critiques, it would be incorrect to view the overall process as a failure. In Abdile's assessment, the most notable success of the process was the consultation and representation of the clans, which, while imperfect, was followed through better than in previous peace processes. Working with clans, he argues, is essential given the structure of Somali society: 'If you want to build a state, you look at the clans...I for example am a Somali, a Muslim and a member of my clan, but the clan comes first. These three support each other but clan is the most important... If decisions are not done respecting this, agreed negotiation results are not respected because the clan support is not there. ${ }^{64}$ As Antti Pentikäinen stresses, the final outcome was generally accepted as legitimate, and the achieved result was not violently contested by the parties that participated. ${ }^{65}$ While opposition was raised, opposition groups - with the important exception of al Shabaab - did not resort to violence.

\footnotetext{
${ }^{63}$ For example, the International Crisis Group commented: 'The current political process has been as undemocratic as the one it seeks to replace, with unprecedented levels of political interference, corruption and intimidation'. See ICG, 'Somalia: From troubled transition to a tarnished transition?', press release, 20 August 2012. The Economist wrote: 'In practice, the "wise men" were largely chosen by existing leaders of the UN-backed transitional federal government (TFG), which has spent the past eight years stealing aid money while leaving AU peacekeepers to fight the Shabab. Money has also played a role in the selection of new MPs. Parliamentary seats were apparently sold for up to US\$25,000’. 'Somalia’s Government, Baby Steps', 25 August 2012.

${ }^{64}$ Interview, Abdile, 2 August 2013.

${ }^{65}$ Interview with A. Pentikäinen, Helsinki, 13 June 2013.
} 